Meta

Journal des traducteurs

Translators' Journal

\title{
Tarantino's Inglourious Basterds: a blueprint for dubbing translators?
}

\section{Nolwenn Mingant}

Volume 55, numéro 4, décembre 2010

De la localisation à la délocalisation - le facteur local en traduction From Localization to Delocalization - The Local Factor in Translation

URI : https://id.erudit.org/iderudit/045687ar

DOI : https://doi.org/10.7202/045687ar

Aller au sommaire du numéro

Éditeur(s)

Les Presses de l'Université de Montréal

ISSN

0026-0452 (imprimé)

1492-1421 (numérique)

Découvrir la revue

Citer cet article

Mingant, N. (2010). Tarantino's Inglourious Basterds: a blueprint for dubbing translators? Meta, 55(4), 712-731. https://doi.org/10.7202/045687ar

\section{Résumé de l'article}

Sorti en 2009, Inglourious Basterds de Tarantino représente une tendance hollywoodienne récente : le film multilingue. L'inclusion d'une langue, voire plusieurs autres que l'anglais peut cependant être problématique, au moment de l'exportation, pour l'équipe chargée du doublage. Cet article se propose de comparer la version originale d'Inglourious Basterds à sa version doublée en français, afin de mettre en lumière un certain nombre de questions de traduction. L'idée d'une relation codifiée avec le public nous mènera d'abord à explorer les questions de convention, de stratagème et de suspension consentie de l'incrédulité, à la fois dans les choix de langue et de sous-titres de la version d'origine et dans la version française. Doubler n'est cependant pas seulement traduire et la question de la texture des voix originales viendra ensuite se poser avec force, notamment autour des problèmes d'accent. Les voix doublées doivent à la fois avoir une texture relativement proche de l'original et sembler plausibles au spectateur français. Enfin, l'opération de doublage se traduit inévitablement par une certaine perte de la place centrale accordée à la langue par Tarantino dans la construction narrative et thématique de son film. Loin d'être un jugement sur le processus de doublage, cet article tente plutôt de mettre en lumière sa complexité et ses réels enjeux.
Ce document est protégé par la loi sur le droit d'auteur. L'utilisation des services d'Érudit (y compris la reproduction) est assujettie à sa politique d'utilisation que vous pouvez consulter en ligne.

https://apropos.erudit.org/fr/usagers/politique-dutilisation/ 


\title{
Tarantino's Inglourious Basterds: a blueprint for dubbing translators?
}

\author{
NOLWENN MINGANT \\ Université Sorbonne nouvelle-Paris 3, Paris, France \\ nmingant@univ-paris3.fr
}

\begin{abstract}
RÉSUMÉ
Sorti en 2009, Inglourious Basterds de Tarantino représente une tendance hollywoodienne récente: le film multilingue. L'inclusion d'une langue, voire plusieurs autres que l'anglais peut cependant être problématique, au moment de l'exportation, pour l'équipe chargée du doublage. Cet article se propose de comparer la version originale d'Inglourious Basterds à sa version doublée en français, afin de mettre en lumière un certain nombre de questions de traduction. L'idée d'une relation codifiée avec le public nous mènera d'abord à explorer les questions de convention, de stratagème et de suspension consentie de l'incrédulité, à la fois dans les choix de langue et de sous-titres de la version d'origine et dans la version française. Doubler n'est cependant pas seulement traduire et la question de la texture des voix originales viendra ensuite se poser avec force, notamment autour des problèmes d'accent. Les voix doublées doivent à la fois avoir une texture relativement proche de l'original et sembler plausibles au spectateur français. Enfin, l'opération de doublage se traduit inévitablement par une certaine perte de la place centrale accordée à la langue par Tarantino dans la construction narrative et thématique de son film. Loin d'être un jugement sur le processus de doublage, cet article tente plutôt de mettre en lumière sa complexité et ses réels enjeux.
\end{abstract}

\begin{abstract}
Released in 2009, Quentin Tarantino's Inglourious Basterds' is representative of a recent trend of multilingual films in Hollywood. The inclusion of one or several languages other than English can be problematic for dubbing translators when the films is exported. The comparison between the original version of Inglourious Basterds and its French dubbed version offered in this article brings to light a number of translation issues. The idea of the codified relationship with the audience leads us to explore notions of conventions, contrivances, and suspension of disbelief, whether in the native language or original subtitling included in the American version. Dubbing is not only translating, it raises the issue of the texture of the original voices, especially in a film preoccupied with accents. Finding French voices with an equivalent texture but which are also plausible for the audience is a challenge that the dubbing team must meet. Finally, the vital importance of languages in the narrative and thematic construction of Tarantino's film result in the inevitable loss due to the dubbing process. This article is not an attack on the dubbing process, but an attempt to interrogate its complexity and determine its role.
\end{abstract}

\section{MOTS-CLÉS/KEYWORDS}

Hollywood, multilingual films, dubbing, cultural positioning Hollywood, films multilingues, doublage, positionnement culturel

"Dubbing is an attempt to hide the foreign nature of a film by creating the illusion that actors are speaking the viewer's language. Dubbed movies become, in a way, local productions" (Danan 1991: 612). Thus did Danan define the role of dubbing in 
a 1991 article entitled "Dubbing as an Expression of Nationalism." She opposed the localizing effect of dubbing to another practice, subtitling, through which viewers "are constantly reminded of the foreignness of a film by the presence of the original soundtrack" (Danan 1991: 613). Danan's opposition between localization/dubbing and foreignness/subtitling still holds true. Some films, however, seem to escape this categorization by posing a strong challenge to the practice of dubbing. According to its director, Inglourious Basterds is one of those films. In an interview given during the 2009 Cannes festival, Quentin Tarantino is said to have declared that "it would not make sense to dub this film." Indeed, how can one dub a film which is about language, a film in which English, French, German and Italian intermingle and interact, a film in which fluency is one of the central "dilemmas" of the characters (Gilbey 2009)? Despite Tarantino's comments in Cannes, a French version of Inglourious Basterds does exist and can be viewed on the DVD.

Inglourious Basterds is not an isolated case. Foreign languages are increasingly part of today's Hollywood films. If most of the films tend to include only one other language (National Treasure: Book of Secret ${ }^{2}$, Vantage Point ${ }^{3}, 2012^{4}$ ), the presence of three or four languages other than English is not rare (Ocean's Twelve ${ }^{5}$, Rush Hour $3^{6}$, Syriana ${ }^{7}$, Babel $^{8}$ ). In that sense, Tarantino's film is less an exception than an example of this recent Hollywood trend. Since the mid-1990s, the foreign market has acquired great economic importance for the American film industry. In order to please and attract foreign audiences, Hollywood films increasingly star foreign actors, and take place in foreign locations. Multilinguism on film is fuelled by a new desire to give a larger and more authentic representation of the non-American world. As in Inglourious Basterds, many Hollywood films, from blockbuster The Last Samurai ${ }^{9}$ to shoe-string budget The Limits of Control $^{10}$ now include several languages in their original version. As in Inglourious Basterds, language itself becomes part of the film's narration. This new trend greatly complexifies the work of dubbing translators. We thus propose to analyze the French dubbing strategy for Inglourious Basterds as a case study of the present trend and the challenges it represents. By comparing the use of language in the original film to the choices made by the French Alter Ego dubbing team, we shall draw up an inventory of dubbing issues and practices. The comparison will look at the codified relationship between a film and its audience, the issue of voice texture, and how dubbing may result in a loss of narrative and thematic construction.

\section{1. "Willing suspension of disbelief": a pact with the audience}

The notion of willing suspension of disbelief is central to the cinematic art. It is part of a pact with the audience. While the film should bring entertainment, the audience tacitly accepts that the heroes never eat or sleep, are capable of superhuman efforts, or that their lives are transformed by a series of coincidences. Language is one aspect of this pact. The American audience has long accepted the idea that every foreign character speaks quite good English, perhaps with a slight accent. Technically, when several languages are involved within one film, the linguistic suspension of disbelief relies on two practices: the use of various conventions to ensure spectatorial comfort and the presence of subtitles. 


\subsection{Conventions and spectatorial comfort}

In order to guarantee maximum comfort for the audience, Hollywood films privilege the use of English. However, this requires artifice to explain how foreign characters speak English. Tarantino explains about 1960s World War II movies, "I don't like those contrivances where everyone is speaking English, or the Nazis are played by members of the RSC or Christopher Plummer or whatever." He defends the idea that such "contrivances" are old-fashioned, that audiences have outgrown this linguistic convention: "Can you imagine an Iraq war movie where the Iraqis are speaking English? You wouldn't buy it for a second" (Gilbey 2009). By insisting on having each character speak his own language and by casting foreign actors to do so, Tarantino rejected these outdated practices, privileging what is usually received as greater realism. Let us look at how the German characters handle English. Five German characters actually interact with the American team: German Colonel Hans Landa, Gestapo Major Hellstrom, actress Bridget von Hammersmark, as well as an officer and a soldier ambushed and interrogated by Aldo in Chapter two. All these characters speak English quite well, except for the German soldier who needs a translator. By introducing one German character who can't speak English, Tarantino underlines his rejection of contrivance - all the other characters can realistically be believed to speak English. Landa, Hellstrom, and the officer are high-ranking members of the army and the police force, they belong to the educated elite of the German nation. As for Landa and Hellstrom, speaking English is a necessary requirement for their police job. As an actress, Bridget belongs to the international world of cinema. On the other hand, it seems logical to assume that a mere German private in the $1940 \mathrm{~s}$ would not be able to speak perfect English. The linguistic deficiencies of this minor character validate Tarantino's linguistic strategy.

In the very first scene of the film, however, we are allowed a moment's doubt about the firmness of the director's linme. Indeed, rustic French farmer Perrier LaPadite speaks near perfect English. Carol O'Sullivan, however, suggests that Tarantino's is not giving in to contrivances, but actually playing with them, seeing the English dialogue between Landa and LaPadite as first and foremost "a wink to the many narrative 'excuses' used in order to allow the speaking of English out of context in Hollywood films." O'Sullivan argues further that the use of English later reveals its true narrative purpose - "to lull the Jewish refugees hidden in the farmhouse into a false sense of security." O'Sullivan explains how -

[b]y exaggerating the use of French and then ostentatiously foregrounding the shift into English (which will be followed by a return to French at the end of the scene), the film asserts its membership of an existing film tradition, in which translation is given little importance, and then subverts it. (O'Sullivan 2010)

Besides giving a sense of realism, Tarantino also takes a stand against the artificial use of language in earlier films, with the usual metafilmic double-entendre that characterizes his work.

If this foregrounding of language in the first scene can indeed be understood as a conscious film buff reference, Tarantino did not however manage to entirely avoid the age-old practice of linguistic contrivance. Indeed, several linguistic choices in Inglourious Basterds, have no justification other than the spectator's comfort. In the tavern scene, for example, when only one German soldier survives the shooting, he 
starts answering Aldo in English. "Your English is pretty good for a German," the American says. "I agree," the soldier answers. Here, the contrivance is obvious. Bridget could not have been used as an interpreter, given the hostile attitude of the soldier towards her. Aldo and the soldier cannot communicate visually, as Aldo is out of sight, on another floor. The only way to make this very short scene work is artifice.

Another example of contrivance is the moment when, in the last chapter, Shosanna and Marcel prepare to shoot the scene they intend to insert in Stolz der Nation and show during the première. As the French girl prepares to recite the message for the German audience, Marcel reminds her:

(1) - Souviens-toi, en anglais.

Remember to speak English. ${ }^{11}$

Again, this appears as a gesture to ensure the American spectator's linguistic comfort. The opposition between the non-English-speaking ambush soldier and the Englishspeaking tavern soldier thus emphasizes Tarantino's dilemma: the discrepancy between the statement he wants to make and its actual feasibility. However, the fact that clear artifice can be spotted only three times in over two hours does speak in favor of Tarantino's efforts.

Questions of spectatorial comfort, suspension of disbelief and linguistic contrivances reappear forcefully during dubbing. Quandaries that Tarantino settled must be asked again, linguistic relationships reexamined. In the dubbed version, the spectator to be assuaged is French-speaking. Suspension of disbelief now requires that most of the characters should speak French. Hence the Basterds' team, Churchill and the British officers, as well as the giant faces of Zoller and Shosanna in the final scene, all speak French. The dubbing team also extended the use of French for French characters. In the introduction scene, Landa and LaPadite originally speak French for 5 minutes, then quickly turn to English for an 11-minute-long dialogue, and return to French for 2 minutes. In the dubbed version, in order to please a French public understandably more comfortable listening to its native tongue, Landa and LaPadite now speak French for most of the dialogue (almost 15 minutes) and only turn to English for 2 minutes. While the dubbing translators only extended the presence of French in this scene, they artificially imposed it over German in the final dialogue between two German-speaking characters, Landa and Bridget, still presumably for the sake of the spectator's comfort.

Maximizing the presence of French dialogue impelled the French dubbing team to resort to new contrivances, either to eliminate the original excuses or to justify the presence of French. The manipulation of the first scene is very successfully managed through the modification of two remarks: one transformed and one added. The pretext given by Landa for speaking English is changed. Originally, Landa said, in perfect and even pristine French, that his French was not good enough and since LaPadite spoke English, could he please continue in English. In the dubbed version, Landa says he loves speaking French but may switch to English for the fun of it, as he knows LaPadite is equally fluent.

(2) In the original version - Je suis au regret de vous informer que j'ai épuisé l'étendue de mon français. Continuer à le parler si peu convenablement ne ferait que me gêner. Cependant, je crois savoir que vous parlez un anglais tout à fait correct, n'est-ce pas? (...) Puisque nous sommes ici chez vous, je vous demande la permission de passer à l'anglais pour le reste de la conversation. 
- I regret to inform you that I have taken my mastery of the French language to its upper limit. Continuing to speak so incorrectly would only embarrass me. However, I believe your command of English is quite satisfactory, is it not? (...) Since we are in your home, I am asking you permission to switch to English for the rest of the conversation.

Inglourious Basterds ${ }^{12}$

In the dubbed version - Je dois dire que c'est toujours avec un grand plaisir que je pratique la langue de Molière. Il se peut néanmoins que je passe à l’anglais pour m'amuser au cours de la discussion et vous me suivrez. Cependant, je crois savoir que vous parlez un anglais tout à fait correct, n'est-ce pas? (...) Puisque nous sommes ici chez vous, je vous demande la permission de commencer en français et de passer à l'anglais tout à l'heure.

- I must say it is always a great pleasure for me to speak Moliere's tongue. I may however switch to English in the course of our discussion, for the sheer pleasure of it, and you will follow me. However, I believe your command of English is quite satisfactory, is it not? (...) Since we are in your home, I am asking you permission to start in French and switch to English later.

Inglourious Basterds ${ }^{13}$

In the original version, Landa starts speaking English immediately after this remark. In the dubbed version, he starts speaking English much later, requiring a renewed linguistic introduction with the replacement of "Now, my job dictates that I must have my men enter your house and conduct a thorough search before I can officially cross your family of my list," by "Oui, maintenant que tout le monde est à l'aise, si l'on s'amusait à parler anglais vous et moi. I need your house to be thoroughly searched before I can officially cross your family off my list." [Yes, now that everyone is at ease, why don't you and me speak English, for amusement's sake? I need your house...] The line is added as Landa is lighting his pipe, both solving any potential lip synchronization problem and thematically linking the introduction of English to the visual cue of a pipe à la Sherlock Holmes.

The two other contrivances previously noted are similarly eliminated. In the tavern scene, Aldo no longer remarks on the German's soldier linguistic capabilities but on the fact that they are enemies. The soldier tells him in French that he is German ("Allemand, espèce de crétin" [German, you cretin]), and the American, instead of remarking on his linguistic abilities, now says "Ah, ça fait qu'on n'est pas dans le même camp, alors!" [I guess that makes us enemies, then], to which the soldier answers, "Ouais, c'est vrai" [Yep, that's right] instead of "I agree." In the same way, Marcel's remark about speaking English is replaced by an innocuous remark on how they should shoot the film ("Tu nous la fait en une prise." [Make it in just one take]).

Beyond eliminating the original justifications for the presence of English, the French team had to deal with other elements which couldn't remain in the French version. Thus, British Lieutenant Hicox's following remarks in the tavern scene would be incomprehensible for a French spectator - "Well, if this is it, old boy, I hope you don't mind if I go out speaking the King's." In French, Britishness shifts from language to nationality: "Hé bien, si c'est réglé, mon cher, je lâche mon rôle et je redeviens le sujet de sa majesté." [Well, if this is it, old boy, I surrender my part to be a subject of his majesty]. Another example of these occasional adjustments is Bridget's remark to Aldo's team. "I know this is a silly question before I ask it, but can you Americans speak any other language than English?" is changed at the end for "... les 
Américains que vous êtes connaissent une langue étrangère?" [.. but can you Americans speak a foreign language?] Both instances point to a specific aspect of suspension of disbelief in non-English speaking countries that dub many American films. Since the 1930s, the French audience has been used to watching dubbed American films. They accept that American characters played by famous American actors speak French, an incongruity that American actors often comment on when traveling aboard (see Bill Murray watching himself speak Japanese on TV in Lost in Translation). Thus, what is problematic in Hicox's and Bridget's remarks is not the allusion to the Britishness or the Americanness of the characters, but only the allusion to the English language itself (since they speak French in the dubbed version). French spectators routinely accept to twice suspend their disbelief, passing over the discrepancy between nationality and language. This enables dubbing translators to solve two very artificial scenes: the French dialogue between Landa and Bridget, when all other German characters speak to each other in German, and the fact that, in the ambush scene, the translation from German to French is provided by an Austrian who has emigrated to the United States.

Dubbing Inglourious Basterds in French thus implies a shift of the linguistic and cultural point of view, as well as a rewriting of the contrivances included in the dialogue. While trying to remain close to Tarantino's efforts to avoid artificially using English, the French dubbing team had to answer to constraints of its own, sometimes stretching credibility. A facilitating element was the fact that the French audience is even more used than the American audience to the linguistic aspects of suspension of disbelief. The French audience is also very much familiar with a second strategy central to multilingual films - subtitles.

\subsection{Subtitles}

The presence of several languages within the same film requires a well-conceived linguistic strategy. If the main character speaks English, the question of whether or not to subtitle the dialogue in other languages remains. Subtitles are also a longestablished convention. The different effects of the presence or absence of subtitles can be briefly described as follows. Assuming the English-speaking characters only speak English, when the foreign lines are not subtitled, the English-speaking audience is in the same position. The film presents a true-to-life communication situation, in which the character and the audience have to guess the meaning from facial expressions and gestures. The absence of subtitles also entails a certain ideological positioning. The audience tends to linguistically and culturally side with the English-speaking characters, mechanically relegating the foreign speaker to the Other. Unsubtitled lines are very often used to create exoticism, for example in adventure movies. On the other hand, subtitled dialogue puts the audience in a position of understanding more than the English-speaking characters, putting them in a linguistic position outside the narrative. This convention is largely accepted, as the audience is used to such privilege through many other cinematic devices, from the use of voice-over to a bird's eye shot. With subtitles, the foreign lines become meaningful, giving the audience an opportunity to identify with the Other. The inclusion of foreign languages, often to ensure a form of authenticity, can thus result in a form of situational realism in the absence of subtitles, or in a more cinematic form of emotional realism, with the inclusion of 
subtitles. Beyond these basic values, linguistic strategies generally vary within the same film, depending on the effect the filmmaker wants from specific scenes.

As Tarantino insists on avoiding the artificial linguistic strategies of 1960s World War II films, he logically chooses to include subtitles, both seeking a certain level of authenticity by including lines in English, French, German, and Italian, and conveying the idea that all languages are equally meaningful. All the dialogue, either in English or subtitled, equally participates in the development of the narration. This linguistic strategy is paradoxically evidenced in two scenes which do not follow the subtitling principle established by Tarantino from the very beginning, with the introductory scene between Landa and LaPadite. When Shosanna and Frederick Zoller meet in a Parisian café (Chapter three ${ }^{14}$ ), the German dialogue between the young man and admiring German soldiers is not subtitled, thus raising Shosanna's - and the audience's - curiosity about him. Alternatively however, in a scene also not concurring with the general subtitling pattern of the film, Tarantino chooses to subtitle more than he needs to. Shortly after the café encounter, Shosanna is ordered by a Nazi officer to step into his car. The officer does not speak French but his instructions need not be subtitled since the chauffeur acts as an interpreter. One line in German, however, is subtitled: "Bedeckt dein Arsch ins Auto" [Get your ass in the car.] By giving the meaning of this line, Tarantino plays on the audience's expectation, implying that she is being arrested, only to reveal in the next scene that she was actually "invited." Indeed, the Nazi officer turns out to be very polite. "Zu Ihrem Dienst, Mademoiselle" [At your service, Mademoiselle], he now tells Shosanna. Thus, while Tarantino made an overall choice to extensively subtitle foreign dialogue, he also uses the full narrative potential of this artificial convention by withholding or revealing information as he sees fit.

This well-conceived linguistic strategy facilitated the French dubbing work. In most of the non-English-speaking scenes, there was no need to change the soundtrack and the team simply translated the subtitles into French. This is the case, for example, of the entire third chapter, which is in French and German. The dubbing team simply changed the linguistic positioning of the film by suppressing the subtitles for the French dialogue and switching the English subtitles to French. The same strategy is applied to the French dubbing of Roland Emmerich's 1998 Godzilla. The film's linguistic pattern can be summarized as follows:

TABLE 1

Languages in Inglourious Basterds (original version and French dubbed version)

\begin{tabular}{|l|l|l|}
\hline Language & Original version & French dubbed version \\
\hline English & language of reference & dubbed in French \\
\hline French & subtitled in English & language of reference \\
\hline German & subtitled in English & subtitled in French \\
\hline Italian & subtitled in English & subtitled in French \\
\hline
\end{tabular}

As appears in Table 1, the only potential problem would be the encounter of original French lines with dubbed French lines. This tricky situation does occur once in the film, in the opening scene, and we have seen how the dubbing artist managed to solve the issue. Fortunately, French Shosanna never meets American Aldo or British Hicox, which greatly simplifies the dubbers' task. But beyond the translation 
and linguistic adaptation involved in dubbing, a second issue must be raised: the rendering of the texture of the original voices.

\section{The Texture of Voices}

In Inglourious Basterds, Tarantino is not simply preoccupied with the authenticity of including several languages and of having each character speak his own language, he is also very much alert to the quality of the language spoken. He is sensitive to the idea that each language comes in different varieties and offers an anthology of variations: British English vs. American English, Southern American English vs. Boston American English, Munich German vs. Frankfurt German. About Hicox's German performance in the tavern scene, Tarantino explains - "And it's not just fluency: he is fluent in German. It doesn't just come down to that. It comes down to dialect, and to whether or not it's your first language" (Gilbey 2009). Speaking the language is not enough, striking the right tone, the right accent, giving the words the right texture is what is at stake.

\subsection{Casting choices and actor direction}

In order to achieve appropriate linguistic texture, Tarantino only uses native speakers to play their own parts. Drawing on the services of casting directors in Paris, Berlin, and Los Angeles, the filmmaker said he was "casting country-appropriate":

[e]very actor had to be from the place they were representing, and they had to be able to speak the appropriate language as well. In other words, it wasn't enough that you could speak German, you had to be German. (Williams 2009)

Nationality more than fame was thus the first criteria, mixing famous stars and promising young actors. The French cast, for example, has beginner Jacky Ido (Marcel) partner with Mélanie Laurent (Shosanna), who was awarded the French César for Most Promising Actress in 2007. For the German parts, Tarantino selected an unknown Austrian television actor (Christopher Waltz as Landa), two German actors who previously played the parts of Hitler (Martin Wuttke) and Goebbels (Sylvester Groth), in Dani Levy's Mein Führer, Die wirklich wahrste Warheit über Adolf Hitler, two prominent young German actors (Daniel Brühl as Frederick Zoller and August Diehl as Major Hellstrom) and a German celebrity actor (Til Schweiger as Hugo Stiglitz).

Since many of the characters had to speak several languages in the course of the film, Tarantino also hired actors who could deliver on that level. He says about Landa that he is

[a] linguistic genius. So I knew if I didn't cast an actor who was himself a linguistic genius, Landa would never be on the screen what he was on the page. I could've cast another actor who might've been terrific, but I would know that there had been compromises. (Gilbey 2009)

Christopher Waltz was thus cast because he could understand and convey "poetry" in English. The Austrian actor is actually fluent in German, English, French, and can manage in Italian. In fact, the linguistic abilities of much of the cast is very impressive. Daniel Brühl (who incidentally started as a dubbing voice actor) speaks 
fluent German, Spanish, Catalan, English, Russian, Italian, and French. Julie Dreyfus, who plays interpreter Francesca Mondino and was Sofie Fatale in Kill Bill 1, speaks fluent French, English, and Japanese. Even the small part of tavern patron Eric is played by German actor Christian Berkel, who is fluent in German, French, and English. Tarantino particularly privileges actors who were raised bilingual, such as German actor Gedeon Burkhard (as Wilhelm Wicki, the Basterd from Austria) or Irish actor Michael Fassbender, who plays British officer Hicox. Fassbender explains how he had to recall childhood memories to speak German fluently again (Comme au cinéma 2009). This multilingual richness entails a high degree of acting skill when it came to working on the texture of dialogue. Diane Kruger (Bridget Von Hammersmark), who is fluent in German, French, and English, explains how "English is not my first language, so I've always had to work at my accent. It's become sort of my specialty - I've played South African, Serbian, and German, obviously" (Paulson 2009). Interestingly, the presence of actors who were not fluent in some of the languages they had to perform in was also conscientiously thought-out by the filmmakers. Thus, producer Lawrence Bender insists that the performance of Denis Ménochet (French farmer LaPadite) mostly rests on the expression in his eyes (Comme au cinéma 2009), while German Til Schweiger's character is intra-diegetically described as "not exactly the loquacious type."

Despite his insistance on authenticity, Tarantino does give linguistic acting instructions for two characters: Bridget Von Hammersmark and Aldo Raine. According to Diane Kruger, Tarantino hesitated before casting her in the role of the German movie star. Basing his judgment on her perfect English in her American movies (Wicker Park, National Treasure), Tarantino doubted her origins (Shoard 2009). Paradoxically, Kruger was almost too fluent in English. She explains: "He actually couldn't believe that I was German, so I had to prove my German-ness to him" (Paulson 2009). In the film, Kruger thus had to abandon her fluent English and don a strong German accent, pronouncing the 'th' as z ('zree,' 'zem,' 'zere') and the w as v ('vant,' 'valk'). Kruger is thus paradoxically asked to overact in order to deliver a more believable performance as a German, according to Tarantino's standard of authenticity. The second clear linguistic direction when it comes to accents is the specific performance of Brad Pitt as Aldo the Apache. The American actor dons a very strong Southern accent, for the character as conceived by Tarantino is a "hillbilly from Tennesse" (Williams 2009; Taylor 2009). This is felt through his intonation, such as the droning pronunciation of "aboutyouall," the drawling $\mathrm{r}$ consonant, the displacement of stresses (carPET), his grammar ("I need me eight soldiers."), and his vocabulary (bushwacking, mountain man, Injun). Although nothing justifies this in the film, interviews reveal that Tarantino wrote this character with a complete backstory in mind. Aldo's nickname and fighting technique are accounted for by his being half-Native American. His accent comes from his past history as a Southerner fighting the racist Ku Klux Klan before World War II (Taylor 2009; Williams 2009). Apparently, Pitt felt so "comfortable" with that accent that he used it between takes (Curry 2009). However, Pitt's accent does appear for what it is, a well-delivered performance for the audience who is used to the star's natural elocution in many other films. Tarantino's quest for authenticity is thus slightly chipped by his asking at least two actors to don an accent different from their own. Another oddity is the acting style of Jacky Ido as Marcel. Although Ido is French and speaks, in the video inter- 
views he has given, without any specific accent (as native born French people of any background are likely to), black actor Jacky Ido speaks a very unnatural French, using the formal nous where a native speaker would use on, and never using contracted forms. No logical explanation comes to mind, all the more so as Mélanie Laurent's French delivery is, on the other hand, standard. The actors are thus required to be authentic and speak the languages their character requires, but only within the bounds imposed by Tarantino's imagination.

\subsection{French voices}

Just as Tarantino's well-conceived linguistic strategy had mapped out the dubbing translator's work, his meticulous approach to the texture of voices had to be equally taken into account. First, as Tarantino chooses French actors for the main French parts, their delivery of the language is, on the whole, natural. The French dialogue therefore does not require dubbing and can be used as such. This is a great advantage for dubbing translators who sometimes have to deal with unauthentic French lines. Furthermore, it must have been very convenient to simply ask Denis Ménochet and Mélanie Laurent to dub themselves in the two scenes in which they speak English. Similarly, as Diane Kruger and Christopher Waltz are both fluent in French, they were able to dub themselves in several scenes.

Not only did the linguistic abilities of the main actors certainly facilitate the dubbing, it helped preserve a certain authenticity. Because at least four characters are voiced by the same actors in the original and in the dubbed versions, the quality and logic of the performance is fully maintained. For example, just as Zoller and Landa speak French with a German accent in the original version, Bridget von Hammersmark speaks French with a German accent in the French version. It is interesting to note, however, that Bridget's accent in French is lighter than in English and more in tune with her natural French delivery, as her French interviews show. The dubbing director may be assumed to have been free not to mimic Tarantino's request in the original version. It might be because the credibility of Landa's and Bridget's French deliveries was clearly established that the dubbing translators chose to bypass realism and dub their last and fateful dialogue in French, in accordance with their speaking English in the original version.

The dubbing director was however confronted with more problematic cases when it came to casting for the English characters: Aldo and his Basterds, Hicox and his superiors. The original actors' lack of skills in French is not a problem: with French being the new language of reference, dubbing by native speakers is the logical choice anyway. But Inglourious Basterds raises the traditional issue of conveying the varieties of the English language in French. Besides the fact that many more varieties seem to exist in English than in French, there is no equivalence between, for example, a Southern American and French accent. By giving a strong Tennessee drawl to one of his main characters and by opposing American and British intonations, Tarantino set a difficult task for the French dubbing team. Two traditional strategies can here be identified in the treatment of the English dialogue: the tendency to neutralize accents, and the recourse to speech registers as a compensation strategy.

Brad Pitt's Southern drawl, a striking element in the original version, completely disappears in Jean-Pierre Michael's rendition of the character. The issue is simple: 
what is the French equivalent to Aldo's Tennessee accent? Let's try and imagine Aldo the Apache with a Southern French accent, for example. A singing intonation from Marseilles or Toulouse would definitely sound inadequate, referring to imaginations of old French comedies with Fernandel or recent comedy Bienvenue chez les Ch'tis ${ }^{15}$. The character might acquire a different persona, as a warm, sympathetic, and potentially comical character. The dubbing directing could have opted for a strong country accent. Aldo is after all a hillbilly, an equivalent of the péquenot or plouc that a French country accent would convey. But again, giving a strong farmer's accent to the character with rolled rs, for example, may lead the audience to dismiss Aldo's character as backward and irrelevant. Indeed, there is arguably a heroic and pioneering quality to the Tennessee accent that is not associated with a French country accent. In the end, trying to find an equivalent would probably be detrimental to Aldo's character, divert the audience's attention and get in the way of the story. The most logical choice was then to simply do away with the accent altogether.

The deletion of Aldo's Southern accent is far from an isolated case. In 2004, the dubbing team on King Arthur ${ }^{16}$ was confronted with the same problem. To express the idea that Arthur's soldiers come from different parts of the Roman Empire, Antoine Fuqua gave them different accents, from the strong cockney of Bors to the Queen's English of Arthur and Lancelot. This aspect vanished in the French version. In order to give a more believable version, a version which sounds more logical and authentic, French dubbing directors almost always neutralize the original English accents. Most Hollywood male actors thus tend to have the neutral voice of a man in his late thirties. Jean-Pierre Michael, a member of the Comédie-Française, not only dubbed Brad Pitt in Inglourious Basterds, but also Keanu Reeves, Jude Law, Christian Bale, and Ben Affleck in various films. In the same way, although British officer Hicox's voice is more high-pitched than Aldo's in the original version, the two voices are much more similar in French. Hicox's dubber, Christian Gonon, also a member of the Comédie-Française, is for example the voice of Mark Darcy (Colin Firth) in Bridget Jones: The Edge of Reason ${ }^{17}$. Suppressing the character's accent means suppressing part of their background, presumably lost on a French audience. In the same way, Churchill's mumbling tone is imitated by the actor who plays him in the original version, as his diction is part of the collective memory in the English-speaking world. This is not replicated in the French version, for French viewers have no such knowledge and cannot appreciate the effort.

In order to compensate for the loss of accents, dubbing translators then turn to another technique, much more meaningful to a French audience: the play on register. If there is no French equivalent to Aldo's drawl, they could still play with the words he uses. The French translation thus refers to Aldo's origin (homme des montagnes) [mountainman], uses swearwords such as foutu le camp, fils de pute, or une putain de trouille [get the hell out / son of a bitch / a fucking scare] and various idiomatic expressions such as ne pas faire dans la dentelle [not for the weak-hearted]. It also plays on grammar, with incorrect forms such as z'avez for vous avez, the absence of the negative form in les Allemands vont pas instead of ne vont pas, and phatic forms such as bon alors [so then], hé ben [well] that are low register. Later on, the dubbing translators also play on the French difference between tu and vous for informal and formal address. In the ambush scene, Aldo says tu to the German officer. It can be a way to show contempt, but saying tu is also very characteristic of a popular register. 
By using specific lexical and grammatical markers, the French version manages to reinsert part of what is lost with the neutralization of Aldo's accent.

Such compensation techniques hardly render the chasm between American English and British English present in the original version. Indeed, Aldo and Hicox tend to have rather similar voices. In most of the scenes, this is of no real consequence. Along with contextual information, a slight inflection of register is enough to convey the characters' nationalities. There is however one scene which is rather awkward: Aldo meeting Hicox just before the tavern scene. Although very short, the pre-tavern scene is reminiscent of the many classical American-British encounters in 1960s World War II films. To try and convey this, the dubbing translators artificially emphasized the characters' linguistic traits, making Aldo more vulgar than usual, both in the words he uses and in his intonation:

(3) - Z'aviez pas dit que z'aviez rendez-vous au fond d'une putain de cave. You didn't tell you was meeting in the pit hole of a fucking basement.

In contrast, Hicox' voice is excessively sophisticated with Don't worry becoming N'ayez crainte or, more interestingly, to get into trouble, a phrase used by both characters in this scene, becoming s'il s'avérait que ça tourne mal [should things turn sour] for Hicox and si des fois ça tourne mal [if things go wrong] for Aldo, des fois being the incorrect form of parfois - sometimes, meaning here perhaps. Yet, in the previous scene, when Hicox is assigned his mission, his British accent and expressions are neutralized in the French version. The necessity to artificially emphasize a difference that is obvious in the original version leads to a certain fluctuation in Aldo's accent in the course of the dubbed movie. This is all the more striking as he reverts to a less picturesque intonation later on in the film: in the veterinary scene immediately after the tavern episode, and in the last interview with Landa. The artificial fluctuation of Aldo's diction thus betrays the dubbing translator's dilemma between giving the character a believable French voice and keeping the opposition with the British character in the pre-tavern scene. It epitomizes the difficulties encountered in dubbing when dealing with specific accents in the original version.

For Tarantino, voice texture was a critical element, which led to the casting of multilingual, non-American actors. The French version respects this by asking the actors to dub themselves. But when it came to dubbing English dialogues, the French team resorted to traditional techniques: the neutralization of accents and compensation through lexical and grammatical choices. Although the French viewers readily accept dubbing conventions they are used to, this strategy occasionally bursts at the seams, revealing its artificiality to an attentive ear. This journey from original to adapted linguistic contrivances, from English to French voices, finally leads us to question the dubbing process in terms of potential losses and inaccuracies. As language is a central element in Tarantino's work, linguistic changes could very well lead to thematic depletion.

\section{Linguistic adaptation and thematic loss}

Subverting the linguistic codes of World War II movies and playing with accents is part of Tarantino's central theme of language in Inglourious Basterds. Dubbing thus implies more than just making the film linguistically understandable to a French audience, it means also possibly intervening on and interfering with Tarantino's artistic endeavor. 


\subsection{Language as a vehicle of narration}

In a previous analysis of recent Hollywood big-budget films, I showed that foreign languages, far from being included only for reasons of authenticity or exoticism, fully participate in the narrative and thematic construction (Mingant 2009). By insisting on language, Inglourious Basterds actually presents a rather thorough inventory of these different narrative and thematic uses.

From the point of view of narrative, foreign languages are first used as shortcuts to quickly present a situation. They are the linguistic equivalent of an establishing shot. This is true of the introduction scene in Inglourious Basterds. The film opens on a quick exchange of remarks in French: a panicked "Papa!" and the pressing answer

(4) - Retournez à l'intérieur; fermez la porte.

Go back inside; close the door.

Together with the "Once upon a time... in Nazi-occupied France" title and the long shot of meadows around the small farmhouse, the use of French establishes the setting. Foreign languages can also be used as shortcuts to characterize the protagonists. Again in the first scene, German officer Landa, with his perfect mastery of three languages, is immediately identified as an astute detective. In the same way, Aldo the Apache is characterized as the "savage" through the language he uses in his first, lengthy speech.

Secondly, foreign languages often serve as comic relief. This is partly true of Italian in the final chapter of Inglourious Basterds. While Aldo's strongly distorted Arrivederci makes us laugh at the Americans' inability to master foreign languages, the scene in which Donny and Omar try to get to their seats and force half a row of Nazis to stand up, repeating scusi and perdon, follows the Hollywood tradition involving ridiculous Italian characters and visual comedy (Vasey 1997).

Finally, foreign languages can be used to create suspense. In Chapter three, two café scenes thus play on Shosanna's inability to speak German. First, as previously mentioned, when Tarantino refuses to subtitle the scene when Zoller is congratulated by German soldiers in front of Shosanna, raising curiosity. The use of German delays the information, creating a feeling of expectation, both felt by the audience and read on Shosanna's face. The revelation comes after a few minutes, when a young French girl accompanying one of the German soldier congratulates Shosanna:

(5) - Vous avez rudement de la veine d'avoir mis la main sur un héros de guerre si courageux.

You lucked out, catching such a brave war hero.

In a second café scene, when meeting Goebbels, Shosanna is again at a disadvantage, as Zoller and Landa are clearly speaking about her in German. Here, the tension is intra-diegetic only, as the subtitles enable the audience to understand the situation. The tension is reinforced by the tight framing on Shosanna's apprehensive face. Already physically trapped at the table by the German characters standing around her, she is rendered helpless both visually and linguistically.

The narrative possibilities of foreign languages are thus extensively used by Tarantino, either as shortcuts, comic elements or suspense builders, and strongly tied up into the narrative. In an interview for Sight and Sound, Tarantino explains what he tried to achieve: 
The reality is that your ability to speak languages in Europe in World War II could be the difference between being shot and thrown in a ditch, or living to see another day. World War II was the last time white people were fighting other white people; you could actually integrate yourself in with the Nazis or the French or whoever, if you could speak the language. It is all about language (Gilbey 2009).

The motif of language as making the difference between life and death is particularly developed in three scenes: the farm scene (Chapter one), the tavern scene (Chapter four) and the final reception scene (Chapter five). The three scenes present three variations of this idea. In the farm scene, language first means the difference between life and death because it is presented as an instrument of deception, with Landa speaking English to trick the unaware Jewish family. In the tavern scene, language is an instrument of disguise as Hicox tries to pass for a German. Unexpectedly, he is not betrayed by his accent, which he manages to explain, but by his inability to fully master the German body language. Indeed, when he gestures to order three drinks, he uses the English sign for three (index, middle finger, annular) and not the German sign (thumb, index, middle finger). Finally, in the reception scene, the American Basterds are exposed as fake Italians by Landa when they turn out to be able only to jabber a few Italian words, with a strong American accent. In these three scenes, the characters' inability to fully master English, German and Italian seal their fate. Tarantino constantly weaves this theme of disguise, linguistically and visually. Thus, before speaking again in French to farmer LaPadite, Landa clearly specifies

(6) - I'm going back to French and I want you to follow my masquerade.

On a visual level, Aldo's carving of swastikas on Nazi foreheads is also a variation on the issue of masquerade. By placing this indelible mark, Aldo renders all deception, either through language or costume, impossible.

Language also means the difference between life and death as it is an instrument of power. Landa and Gestapo Major Hellstrom are both in a position of superiority thanks to their linguistic abilites: Landa speaks four languages and Hellstrom can tell apart accents from different parts of Germany. They use this power to try and unsettle the people they are interrogating, respectively in the farm scene and in the tavern scene. Another expression of Landa's linguistic power is when he incongruously assumes the position of a schoolmaster, teaching Italian pronunciation to Bridget's supposedly Italian guests. "One more time, but let me really hear the music in it," he says to them in Italian. The link between language, deception, and power is thus explored throughout the film.

As mastering several languages becomes a necessity to survive in Tarantino's World War II Europe, a recurrent figure in the film is the go-between. Four characters speak both German and French and act as interpreters: Zoller, the French girl in the café, Goebbels' female translator Francesca, and Bridget. As interpreters of languages and, possibly, cultures, these four characters are all related to an underlying motif of sex, the ultimate link. Zoller is wooing Shosanna. The girl in the café is dating the German soldier. Goebbels's interpreter is revealed to be his mistress. Bridget is the stereotype of the movie sex symbol. But Inglourious Basterds does not envisage sex as a romantic linguistic and cultural union. It is rather a fight, a locus of violence, a fateful encounter. The very short sex scene between Goebbels and his translator both epitomizes the violence of the relation - Goebbel's energy is rather 
brutal - and the way it is imposed on the woman, seen on Francesca's resigned face. For Carol O'Sullivan, this scene is "dismissive of the interpreter's role and of her point of view” (O’Sullivan 2010: electronic source).

If the relationship between power, language and violence is made absolutely clear in the case of the translator, it is underlying for all the other go-between figures. Zoller is first presented as a tender, romantic man, hoping to woo a French Parisian. His first encounter with Shosanna is quintessentially romantic. Zoller looks up at Shosanna who is standing on a ladder, as she would on a balcony. Just as in Shakespeare's Romeo and Juliet, the two will end up causing each other's violent death. In the same way, although the young girl dating a German soldier in the café is presented as cheerful and joyous, one cannot but think of the fate of women who were shaved, brutalized, and driven away by the French population in the immediate aftermath of World War II for having had affairs with the occupying German forces.

Another prominent go-between figure is German officer Landa. He is the ultimate epitome of the link between language, power, sex, and violence. Indeed, one could safely say that Landa's use of language is rather perverse. In the farm scene, he seems to enjoy very much farmer LaPadite's breaking down as he calmly stares at his sweating face. In the same way in the last chapter of the film, he enjoys playing with Bridget's foot in his hand, sensuously slipping the shoe, which happens to be the evidence of her betrayal. "Voilà," he tells her in French with delight. Both are moments of perverse linguistic pleasure, ending in a climax. In the farm scene, a strident music starts as LaPadite confesses and the climax, for both ears and eyes, is reached when the German soldiers discharge their guns on the Jewish family. At the end of his interview with Bridget, Landa is at a loss for words and seeks final relief by assaulting Bridget and strangling her. So, just as the other go-betweens, Bridget, the treacherous sex-symbol, was doomed from the start. Beyond the three central scenes (the farm, the tavern, the reception) which thematically develop the issue of language as instrument of life and death, Tarantino thus recurrently develops this motif through a series of ill-fated go-between figures.

In the fifth chapter, narrative and thematic uses of languages come together to lead the film to its final climax. Indeed, whereas each chapter tended to concentrate on two main languages, four languages coexist in the last chapter, changing at a much faster pace with no more lengthy scenes in each language. What is more, other languages suddenly intrude in scenes dedicated to a specific language: Italian or French in German scenes, for example. This is partly due to a strong acceleration in editing towards the end of the chapter, with more than a dozen extremely short scenes (from a few seconds to a few minutes) in the twelve minutes before the fire breaks out, quickly juxtaposing parallel actions: the film screening, Hitler speaking to Goebbels, the American agents trying to approach Hitler, Marcel and Shosanna preparing to set the theatre on fire, Landa calling Aldo's superior, Zoller trying to seduce Shosanna. All this parallel editing between various characters inevitably results in various languages colliding, leading to the chaotic and climactic finale, in which a French girl screams in English at a German audience. Tarantino's use of multilinguism to enhance the theme of power, survival, and violence, is bound to be somewhat lost in the dubbing process. 


\subsection{Dubbing as a loss}

Let us go back once more to the very first scene of the film. In the original version, Landa starts in French then quickly turns to English as he interrogates the French farmer, and goes back to French again at the very end of the scene. In the French version, the two men speak French for most of the scene, using English only for about two minutes towards the end. The French dubbing translator chose to extend the French dialogue for the spectator's comfort, but kept the few lines in English necessary to the plot. Technically, it implied transforming the first allusion to the English language and adding a second allusion later in the scene.

Thematically, the dubbing led to some elements being kept while others were lost or added. By retaining two minutes in English, the French version manages to maintain the narrative and thematic role of language. It still makes the difference between life and death, as the Jewish family does not understand they are being betrayed. It is still an instrument of deception, as Landa's allusion to his "masquerade" is kept. On the other hand, the scene loses in dramatic intensity. Originally, the audience could feel the pressure put on the farmer by the long questioning in English. This slow build-up in psychological tension led to the farmer breaking down and confessing the presence of the Jewish family. In the French version, there is not such crescendo and the confession seems quite sudden and unmotivated. To some degree, a mechanism necessary to make the scene work was lost. But two elements were also added to the scene in the French version. First, the translator had to find a plausible reason for the presence of English lines. While in the original version, Landa says his English is better than his French, in the dubbed versions he suggests speaking English "for amusement's sake" ("pour m'amuser"). While the original excuse is about the character's linguistic abilities, the French excuse is about his personal taste, which modifies our first impression of him. On the other hand, the French version adds a certain degree of authenticity to the scene. Indeed, in the original version, the audience is asked to believe that a 1940s French farmer would be quite able to sustain a conversation in good English, using complex vocabulary and structures, such as in the following sentence:

(7) - I've heard that the Führer has put you in charge of rounding up the Jews left in France while they are hiding or passing for Gentiles.

Although this might pass very well with an English-speaking audience used to foreigners speaking English, it seems rather absurd to a French audience. In the French version, on the contrary, the farmer's English lines are reduced to "yes," which seems much more realistic. The scene thus becomes very convincing from a French point of view.

Should these two additions be interpreted as betrayals of Tarantino's intentions? In fact, the additions do not appear ex nihilo, but are transferred from other scenes or themes of the film. The idea that Landa wants to amuse himself by speaking English echoes the final chapter when Landa first scares Bridget, only to tell her that it is a mere Scherz [a joke]. "Nein, ich mache nur Scherze, mein gnädiges Fräulein. Sie kennen mich doch. Mein Scherze sind ein bissl grob.” [No, I'm just teasing you, Fräulein. You know I tease rough]. The perverse technique of mixing threat and laughter is thus built into Tarantino's original character. Besides, Landa's excuse for speaking English in the first scene can never be accepted at face value by the audience, as his French is 
more than perfect. The hidden motive is obvious. The French translation thus follows Tarantino's logic by emphasizing a psychological trait of the German character developed later in the film. By presenting Landa, the Jew hunter, as a man eager to amuse himself by playing cat and mouse with the Jews he calls rats hiding under the floor, the French translators manage to remain faithful to Tarantino's original intentions. In the same way, the added authenticity of the scene for a French audience cannot be considered a betrayal. Although the director might not have been looking for authenticity in this specific scene, it seems consistent with Tarantino's overall approach.

Just as this first scene, the rest of the dubbed version is a balanced negotiation between strict fidelity to the original and careful interpretation. The original artificiality is sometimes lost, with the French farmer in the first scene, but also with Marcel preparing to shoot in one take instead of remembering to speak English. On the contrary, artificiality is introduced when Landa and Bridget start speaking French to each other, as opposed to German. Artificial and authentic scenes may thus be said to cancel each other. On the whole, the French version does convey the same narrative and thematic uses of language as the original version. This was partly made possible through the fact that many segments of the original soundtrack could be kept. The French and German scenes involving Shosanna, in which language is an element of suspense, are unchanged, except for the subtitles. The roles of Zoller and the young French girl in the café as tragic go-betweens remain the same. The central scenes of the farm and the tavern (for which the soundtrack was hardly modified at all) also continue to explore the themes of language as an instrument of power and survival. Even the role of Italian is carefully kept through a subtle intervention of the dubbing translators. The humor of the original confrontation between Landa and the Basterds being that they speak Italian with an English accent, the comic situation works in French by having the line re-dubbed by actors speaking Italian with a French accent. The logic is maintained and the joke works. On the whole, it can be said that the dubbed version is quite faithful to Tarantino's original approach.

Can we go as far as saying that the slight losses and transformations due to translation is only marginal and does not impact the film? One element of translation that was unexplicably transformed is the typography of the chapter titles. In the original version, the mention of each chapter is underlined and the title, in capital letters, is centered. In the French version, chapter numbers and titles appear at the bottom of the screen, where the subtitles would be. Whereas the first typography was elaborate, as in a fancy book, the second typography is basic, unsophisticated, and seems only utilitarian, deleting minor elements, such as the date in Chapter three. Typography is obviously important to Tarantino, as shown by the superimposition of text in large black and orange letters in Chapter two ('Hugo Stiglitz') and three ('Shosanna Dreyfus'). A certain poetry, constructive of the film's atmosphere, is lost in this typographical transformation.

Also lost are all the intra-diegetic allusions to the English language, the King's English as Hicox says, replaced by him being the King's subject. Also lost is Landa's nursery rhyme-inspired "And you need all four to end the war" in his interview with Aldo. Individually, these transformations are not paramount. Collectively however, their accumulated loss of reference to the English language contributes to the shift from the American to the French cultural point of view. 
The dubbing process leads not only to a cultural displacement, but also to significant thematic and narrative transformations. The role of Goebbels' interpreter, for example, is much more important in the dubbed version. Originally, Goebbels' lines in German are subtitled in English. When Francesca translates in French for Shosanna, she is consequently not subtitled. In English, people understand neither German nor French, it is thus logical to subtitle the first occurrence, i.e., German, with the interpreter being useful only to Shosanna, not to the audience, and therefore rendered mute to the ears of an non-French speaker. The interpreter's words are of no significance to the story. This subtitling strategy is in keeping with the short sex scene in which the interpreter is shown as the compliant mistress of Goebbels. In Tarantino's original version, the character of Francesca is representative of a certain submission of language to brutal force. In the French version, Goebbel's German lines are not subtitled any more and the audience's understanding of the situation entirely depends on Francesca's translation. In French, the interpreter is useful for the audience as well since they are in Shosanna's position. This logical dubbing choice quite inadvertently gives a new significance to Francesca's character. The sex scene then appears more as a humorous moment revealing that "interpreter" is an understatement for "mistress." It can also be an echo of the character of the young girl dating the German soldier, and we can clearly see on Shosanna's face that she disapproves of this kind of collaboration. By being given a voice in the French version, Francesca is given a story. By foregrounding Francesca's words, the dubbed version pads out her role, transforming the allegory into a flesh-and-blood character.

Let us finally turn to Chapter five, which is also affected by the dubbing process. In the original version, the fast pace switch from one language to another accompanied the editing choices leading to the chaotic finale. Just as LaPadite's interrogation in French loses in psychological intensity, the rise of tension is less important in the dubbed ending. In the original version, one language would suddenly resurface in a scene dedicated to another language. While Landa interrogates Bridget in German, he suddenly blurts out in French and English: "Voilà! What's that American expression? If the shoe fits, you must wear it." In the dubbed version, the dialogue is entirely in French. The colliding of languages, and Landa as the fine clock suddenly breaking down, was preparation for the complete disorder of the finale. No such psychological or thematic preparation exists in the dubbed version. In the same way, the original final fire scene is nightmarish, partly because of the illogical linguistic patterns, in which the relationship between communication and language appears as broken. In the middle of a German film, an instrument of propaganda certainly made for a German audience, Zoller's character suddenly starts to yell at the audience in English, immediately followed by the interruption of Shosanna's face. Not only is the French girl yelling in English to a German crowd, but she also shouts in English "Marcel, burn it down," to which her lover answers in French, "Oui, Shosanna." The linguistic logic is breaking down, participating in the general chaos. The choices of the dubbed version smoothes all of this over. Although Zoller's suddenly yelling in French is still illogical, it is quite natural to hear Shosanna yelling in her own language, ordering her lover to burn the cinema in French. Her use of French to address the German audience is also quite logical since it is her native language and the premiere takes place in Paris. By reintroducing some logic into the language pattern, the dubbing translators let all the depiction of chaos rest on the quick editing and the loud 
soundtrack, dominated by Shosanna's laugh, the crowd's screams, and the Americans' shooting guns.

In Chapter five, the neutralization of the role of language leads to a major narrative loss. Switching the cultural point of view of the film changes the significance of the character of the interpreter as an allegory of the violent relationship between language and power, and partly erases the value of the disconnection of language as a symptom of chaos, straying away from Tarantino's original intentions.

\section{Conclusion}

In the end, how then can we assess the French dubbed version? Through a constant process of negotiation, the search for logical equivalence, and meticulous efforts, the dubbing team managed, on the whole, to remain faithful to Tarantino's project. It would therefore be excessive to describe the dubbing process merely in terms of loss or depletion. Notions of transformation, shifts and displacement seem more adequate. There is indeed a significant process of reinterpretation at work here. In that sense, the French dubbed version is not only a translated version of Tarantino's Inglourious Basterds, but rather a new version of the film. After the director's cut, one could, rather provocatively, introduce the idea of the "dubber's cut." But beyond the dilemma of fidelity vs. betrayal, what is the actual role of dubbing? Dubbing strives at making a film accessible to an audience, not simply by translating the dialogue and subtitles, but by localizing or naturalizing the film, by changing the reference frame. This implies translating the dialogue, but also the cultural allusions, adapting to local dubbing conventions, finding convincing voices. Erasing the allusion to the English language, resorting to double suspension of disbelief, neutralizing the male voices are all elements which makes the film more acceptable for the French audience, because it corresponds to what is considered natural, what is expected from a dubbed version. In spite of all the betrayals to and accommodations with the original, the dubbing process fulfills its role as it does enable French spectators to have access to the Tarantino's work and understand his authorial intentions.

So to answer Tarantino's assertion, does it make sense to dub Inglourious Basterds? Probably not, since Tarantino wanted each nationality to match the language. Is it therefore impossible to dub Inglourious Basterds? No, it is not. And the dubbing team's efforts result in a French version which is praiseworthy. In fact, their work was certainly facilitated by Tarantino's thorough linguistic reflection. It is certainly much more difficult to dub films in which foreign lines are included as mere signs of exoticism, and often delivered in an non-authentic way. The work on the original text plays a fundamental role in the final result. As more and more Hollywood films include one or several languages other than English, the efforts shown in dubbing Inglourious Basterds are going to be more and more widespread and Tarantino's film may very well be used as a blueprint.

\section{NOTES}

1. Inglourious Basterds (2009): Directed by Quentin TARANTINO; French version: Inglourious Basterds (2009). Universal; 2010.

2. National Treasure: Book of Secret (2007): Directed by John Turteltaub.

3. Vantage Point (2008): Directed by Pete Travis. 
4. 2012 (2009): Directed by Roland EMmerich.

5. Ocean's Twelve (2004): Directed by Steven SODERBERGH.

6. Rush Hour 3 (2007): Directed by Brett RATNER.

7. Syriana (2005): Directed by Stephen Gaghan.

8. Babel (2006): Directed by Alejandro González IÑárRitu.

9. The Last Samurai (2003): Directed by Edward Zwick.

10. The Limits of Control (2009): Directed by Jim Jarmusch.

11. The sentences translated by the author appear in italics.

12. Inglourious Basterds (2009): Directed by Quentin TARANTINo; French version: Inglourious Basterds (2009). Universal; 2010.

13. Inglourious Basterds (2009): Directed by Quentin TARANTINO; French version: Inglourious Basterds (2009). Universal; 2010.

14. Inglourious Basterds is divided in five chapters, for example: "Chapter three: German Night in Paris."

15. Bienvenue chez les Ch'tis (2009): Directed by Danny Boon.

16. King Arthur (2004): Directed by Antoine FUQUA.

17. Bridget Jones: The Edge of Reason (2004): Directed by Beeban Kidron.

\section{REFERENCES}

Comme Au cinéma (2009): Notes de production, chapitre 2: le casting. Comme au cinéma. Visited 22 March 2010, <http://www.commeaucinema.com/notes-de-prod/inglouriousbasterds,71265-note-69878>.

Curry, Ann (May 2009): Curry in Cannes, Brad Pitt one-on-one. NBC. Visited 22 March 2010, $<$ http://www.youtube.com/watch?v=YloLnrITsyw $>$.

Danan, Martine (1991): Dubbing as an Expression of Nationalism. Meta. 36(4):606-614.

Gilbey, Ryan (August 14 2009): Entrevista a Quentin Tarantino (Sight \& Sound). Micropsia. Visited 22 March 2010, <http://micropsia.blogspot.com/2009/08/entrevista-quentintarantino-sight.html>.

Mingant, Nolwenn: Plurilinguism, Exoticism and Authenticity in Contemporary Hollywood Cinema (XIV Congrès de la SERCIA, Le cinéma parle: mots, voix et langue, Nanterre, 17-19 September 2009).

O'Sullivan, Carol (February 21, 2010): Tarantino on Language and Translation. MA Translation Studies News. Visited 22 March 2010, <http://matsnews.blogspot.com/2010/02/tarantinoon-language-and-translation.html>.

Paulson, Robin (August 9, 2009): Diane Kruger Talks 'Inglourious Basterds,' Karl Lagerfeld. Movies.gearlive. Visited 22 march 2010, <http://movies.gearlive.com/movies/article/q107diane-kruger-talks-inglourious-basterds-karllagerfeld/>.

ShoArd, Catherine (May 29, 2009): Killer Heels and a Prize Turkey Guardian.co.uk. Visited 22 March 2010, <http://www.guardian.co.uk/film/2009/may/29/diane-kruger-quentintarantino-inglourious-basterds $>$.

TAYLOR, Ella (August 18, 2009): Quentin Tarantino: The Inglourious Basterds interview. The Village Voice News. Visited 22 March 2010, <http://www.villagevoice.com/2009-08-18/news/ quentin-tarantino-the-inglourious-basterds-interview/3>.

VASEY, Ruth (1997): The World According to Hollywood, 1918-1939. Madison: University of Wisconsin.

Williams, Kam (August 10, 2009): Quentin Tarantino “Inglourious Basterds" Interview with Kam Williams. News Blaze. Visited 22 March 2009. <http://newsblaze.com/story/2009 0810110253kamw.nb/topstory.html>. 